\title{
The Effect of Striking and Fielding Games on Fundamental Movement Skills
}

\author{
Vicki Ahmad Karisman*, Dedi Supriadi \\ Physical Education and Health Dept. \\ STKIP Pasundan \\ Cimahi, Indonesia \\ *vicky4kharisman@gmail.co
}

\author{
James Tangkudung \\ Physical Education Dept. \\ Postgraduate Universitas Negeri Jakarta \\ Jakarta, Indonesia
}

\begin{abstract}
This study was aimed at exploring the contribution and the use of striking and fielding games in elementary school as an attempt at improving student's fundamental movement skills. The researcher utilized an experimental method with pretest and posttest control group design. This study employed 39 4th grade students as the research samples who were selected by implementing a total sampling technique. The treatment was given in 16 meetings. For the instrumentation, the researcher used Test Gross Motor Development (TGMD) the 2nd edition; which was divided into two kinds of tests, including 6 items of locomotor test and 6 items of object skill test. A series of games were undertaken to improve the fundamental movement skills, namely baseball, kippers, slag balls, and rounder. Paired Samples Test results showed a significance value $(0,000)$ from the students' pretest and posttest scores. Because the significance in the pretest and posttest scores of fundamental movement skills was $<0.05$, it means that there is a significant influence. Based on the data analysis, it revealed that there was a significant improvement of striking and fielding games on students' fundamental movement skills.
\end{abstract}

Keywords: fundamental motor skill, physical education, striking and fielding

\section{INTRODUCTION}

Fundamental Movement Skills (FMS) are defined as a basic pattern of learning that does not occur naturally but becomes the basis of physical activities and sports to the more complex one. This FMS can be classified into three different categories: locomotor (involving body movements, for example, running), object control (manipulative skills, for example, catching a ball) and stability skills such as balancing $[1,2]$. The children who are physically active developed more on their fundamental movement skills and health than those who do not. Fundamental movement skills are the building blocks of more advanced, complex movements which are needed while undertaking the games, sports or other specific context of physical activities [3].

Fundamental movement skills are important in a child's growth and development. Fundamental movement skills mastery, however, might provide many benefits, especially in carrying out various physical activities. If a person has the opportunity to exercise more during childhood between the ages of 2-7 continuously, the fundamental movement skills will be developed as well. Those skills become the basis of their success while doing any sports [4].

Fundamental movement skills cannot be possessed easily. In other words, it can be possessed by doing various programs. This fundamental movement skills are not possessed naturally during the maturation process [5]. However, the teachers need to design and carry out activities appropriately in accordance to the students' development, specifically while teaching and learning (with feedback) during the its process by providing sustainable physical activity [6]. Previous studies revealed the positive impact of utilizing proper activities while class-break. In which, the class-break could be the alternative way for the teacher or instructor to promote students' fundamental movement skills [7]. Previous study showed the fact that a girl with low fundamental movement skills had a higher body mass index and higher percentage on their body fatness compared to them who does [8,9]. It is recommended further to develop interventions toward the students for long-term participation in physical activity. Because, the fundamental movement skill and self-confidence of every student might be different, thus, there will be a different treatment too [10].

FMS can be taught and practiced in games. Whether it is structured or not. This should be integrated into the curriculum used [11]. In their practice, the students will perform their skill in game-play contextually. Moreover, the teacher or instructor, simultaneously, should show his/her understanding of material and ability in controlling the game. Thus, the teaching and learning might be balance [12]. In the physical education context, any game is considered as the best experience to the students' reflective learning [13]. The game that might facilitate those things are striking and fielding games.

Striking and fielding games are the activities in which the players could make a points by hitting the object (ball) and running to the base area or preventing the opponent team from point-making by taking the object (ball) and returning it to stop the game. Through the game, the students learn the fundamental movement skill and its tactics as well by their own experience and observation.

Essentially, these games contain the various kind of fundamental movement skill, both the locomotor and object 
skill. Such as walking, running, jumping, rolling and hitting, throwing, and catching the ball. In Indonesia, the striking and fielding games that most frequently played are kasti, baseball, rounders, slag ball, and kippers. Basically, those games provide the students opportunity to develop their fundamental movement skills.

\section{METHOD}

This study administered experimental method with pretest and posttest group design. The population were the 4th grader students of elementary school. 34 students were employed as the research sample selected through total sampling technique. The study was conducted in 16 meetings with four kinds of striking and fielding games. Those were kasti, kippers, rounders, and slag ball. The instrument used was Test of Gross Motor Development (TGMD) the 2nd Edition [14]. Six types of locomotor tests included are running, galloping, hopping, leaping, horizontal jumping and sliding. Six types of object skill tests, namely striking a stationary ball, stationary dribbling, catching, kicking, overhand throwing, and underhand rolling. Analysis and processing of data used the SPPS 21 with paired sample t-test.

\section{RESULTS AND DISCUSSION}

\section{A. Results}

Based on the analysis and processing data, it obtained the following results:

TABLE I. RESULT RESEARCH

\begin{tabular}{|c|c|c|c|c|c|c|c|c|}
\hline & \multicolumn{5}{|c|}{ Paired Differences } & \multirow{3}{*}{$\mathbf{t}$} & \multirow{3}{*}{ df } & \multirow{3}{*}{$\begin{array}{l}\text { Sig. } \\
(2- \\
\text { tailed) }\end{array}$} \\
\hline & \multirow[t]{2}{*}{ Mean } & \multirow[t]{2}{*}{$\begin{array}{c}\text { Std } \\
\text { Deviation }\end{array}$} & \multirow[t]{2}{*}{$\begin{array}{l}\text { Std } \\
\text { Error } \\
\text { Mean }\end{array}$} & \multicolumn{2}{|c|}{$\begin{array}{c}95 \% \\
\text { Confidence } \\
\text { Interval of the } \\
\text { Difference }\end{array}$} & & & \\
\hline & & & & Lower & Upper & & & \\
\hline $\begin{array}{l}\text { FMS } \\
\text { Pre - } \\
\text { Post }\end{array}$ & -6.857 & 9.477 & 2.532 & -12.329 & -1.384 & $-\overline{2.707}$ & 13 & .000 \\
\hline
\end{tabular}

Results: Paired Samples Test results on the pre-test and post-test of fundamental movement skills showed a significance value of 0,000 . Because of the significance of the pretest and post-test data of basic motor skills is $<0.05$, it can be concluded that there was a significant effect of striking and fielding games on the students' fundamental movement skills.

\section{B. Discussion}

Based on the findings, it showed that there was a significant effect of striking and fielding games on the students' fundamental movement skills. It caused by the contribution of both striking and fielding games to some aspect of fundamental movement skills; those are running speed, agility, balancing, also eye and hand coordination. Indeed, both striking and fielding games characteristics might support the running speed, agility, balancing, also eye and hand coordination as well [15]. Besides, the various techniques in kasti, baseball, rounders, slag balls and kippers - such as walking, running, jumping, throwing, catching, and hitting the ball - facilitate the students to improve their fundamental movement skills.

The striking and fielding games potentially to the following aspects: (1) facilitating the technical skills and tactical knowledge development; (2) empowering children to learn on their own and be responsible on what they did; (3) providing the tactical understanding; and (4) increasing students' pleasure and enjoyment in playing games [16]. The game-based approach is loaded with the assignments given to the students. In which, that could stimulate them to think and discover the rationales underlie their movement skills performance. This approach provides students with an understanding of the benefits of their action and attitude. Thus, they were given many opportunities to assess themselves and their ability during the learning process [17]. Through the variety of games, the students facilitated to improve their fundamental movement skills even better.

Another character of striking and fielding games is the lower level of speed compared to the invasion games and net game. This character is beneficial to decrease the trickiness. In addition, this character could give the students a spare time to make a decision [18]. Students have plenty of time to learn various techniques through the games which might enhance their fundamental movement skills as well.

The fundamental movement skills develop as the game is play. Furthermore, the fundamental movement skills contextually taught together in the game [19]. The games provide the opportunities to acquire knowledge about something, train the imagination, provide opportunities to interact with the surrounding environment and to express themselves that socially acceptable [20]. Thus, the learning which is undertaken through the games especially striking and fielding games - including kasti, baseball, kippers, slag balls, and rounders - have a significant effect on the students' fundamental movement skills.

\section{CONCLUSION}

Based on the data analysis and processing, it can be concluded that striking and fielding games have a significant effect on the students' fundamental movement skills. It is recommended for further research to use any other modern games in accordance with the current development.

\section{REFERENCES}

[1] D. L. Gallahue, J. C. Ozmun, and J. D. Goodway, Understanding motor development: Infants, children, adolescents, adults, 7th ed. McGrawHill, 2012.

[2] J. D. Goodway et al., "A Developmental Perspective on the Role of Motor Skill Competence in Physical Activity: An Emergent Relationship," Quest, vol. 60, no. 2, pp. 290-306, 2012.

[3] S. W. Logan, S. M. Ross, K. Chee, D. F. Stodden, and L. E. Robinson, "Fundamental motor skills: A systematic review of terminology," $J$. Sports Sci., vol. 36, no. 7, pp. 781-796, 2018.

[4] U. Senturk, M. Beyleroglu, F. Guven, A. Yilmaz, and H. Akdeniz, "Motor skills in pre-school education and affects to 5 year old children's psychomotor development," Turkish J. Sport Exerc., vol. 17, no. 2, p. 42,2015 . 
[13] P. Lavega, Q. Prat, U. S. De Ocáriz, J. Serna, and V. Muñoz-Arroyave, "Reflection-on-action learning through traditional games. The case of la pelota sentada (sitting ball) $\mid$ Aprendizaje basado en la reflexión sobre la acción a través de los juegos tradicionales. El caso de la pelota sentada," Cult. y Educ., vol. 30, no. 1, pp. 142-176, 2018.

[14] D. A. Ulrick, Test of Gross Motor Development 2. 2000.

[15] R. Pulung, "Pengaruh Permainan Bola Kasti Terhadap Peningkatan Kemampuan Gerak Umum (General Motor Ability)," J. Sport Area, pp. 53-63, 2014

[16] L. Wang and A. S. Ha, "Three groups of teachers' views, learning experiences, and understandings of teaching games for understanding," Phys. Educ. Sport Pedagog., vol. 18, no. 3, pp. 336-350, 2013.

[17] H. Singgih, "Aplikasi Pendekatan Bermain untuk Meningkatkan Efektivitas Pembelajaran Bola Voli Kelas VIII SMP Al Islam 1 Surakarta Oleh : Singgih Hendarto 1," pp. 309-322, 2012.

[18] J. L. Fisette and S. Mitchell, "Frameworks for Diagnosing Student Performance Problems in Striking/Fielding and Target Games," JOPERD J. Phys. Educ. Recreat. Danc., vol. 81, no. 8, pp. 43-56, 2010.

[19] L. M. Barnett et al., "Fundamental Movement Skills: An Important Focus," J. Teach. Phys. Educ., vol. 35, no. 3, pp. 219-225, 2016.

[20] M. M. Suherman, "Efektivitas Strategi Permainan Dalam Mengembangkan Self-Control Siswa," 2014.

[11] A. L. \& W.Piltz, Play Practice-2nd Edition, 2nd ed. Human Kinetics, 2013.

[12] D. Dudley and D. Baxter, "Metacognitive analysis of pre-service teacher conception of Teaching Games for Understanding (TGfU) using blogs," Asia-Pacific J. Teach. Educ., vol. 41, no. 2, pp. 186-196, 2013. 